\title{
Evaluation of Factors Affecting Soil Carbon Sequestration Services of Stormwater Wet Retention Ponds in Varying Climate Zones
}

Merriman, L.S. ${ }^{1 *}$, Moore, T.L.C. ${ }^{2}$, Wang, J.W. ${ }^{3}$, Osmond, D.L. ${ }^{4}$, Al-Rubaei, A.M. ${ }^{5}$, Smolek, A.P. ${ }^{1}$, Blecken G.T. ${ }^{5}$, Viklander, M. ${ }^{5}$, and Hunt, W.F. ${ }^{1}$

*Corresponding Author: laura.merriman@amecfw.com (L.S. Merriman) Present Address: 9711 Sky Park Court, San Diego, California, USA 92123-4341

${ }^{1}$ Biological \& Agricultural Engineering, North Carolina State University, Campus Box 7625, Raleigh, NC, 27695, United States

${ }^{2}$ Biological \& Agricultural Engineering, Kansas State University, 129 Seaton Hall, Manhattan, KS, 66506, United States

${ }^{3}$ Centre for Urban Greenery and Ecology, National Parks Board, 1E Cluny Road, Singapore 259569

${ }^{4}$ Soil Science, North Carolina State University, Campus Box 7619, Raleigh, NC, 27695, United States

${ }^{5}$ Urban Water Engineering, Luleå University of Technology, SBN 97187 Luleå, Sweden

\section{Abstract}

The carbon sequestration services of stormwater wet retention ponds were investigated in four different climates: U.S., Northern Sweden, Southern Sweden, and Singapore, representing a range of annual mean temperatures, growing season lengths and rainfall depths: geographic factors that were not statistically compared, but have great effect on carbon (C) accumulation. A chronosequence was used to estimate $\mathrm{C}$ accumulations rates; $\mathrm{C}$ accumulation and decomposition rates were not directly measured. C accumulated significantly over time in vegetated shallow water areas $(0-30 \mathrm{~cm})$ in the USA $\left(78.4 \mathrm{~g} \mathrm{C} \mathrm{m}^{-2} \mathrm{yr}^{-1}\right)$, in vegetated temporary inundation zones in Sweden (75.8 $\left.\mathrm{g} \mathrm{C} \mathrm{m}^{-2} \mathrm{yr}^{-1}\right)$, and in all ponds in Singapore (135 $\left.\mathrm{g} \mathrm{C} \mathrm{m}^{-2} \mathrm{yr}^{-1}\right)$. Vegetative production appeared to exert a stronger influence on relative $\mathrm{C}$ accumulation rates than decomposition. Comparing among the four climatic zones, the effects of increasing rainfall and growing season lengths (vegetative production) outweighed the effects of higher temperature on decomposition rates. Littoral vegetation was a significant source to the soil $\mathrm{C}$ pool relative to $\mathrm{C}$ sources draining from watersheds. Establishment of vegetation in the shallow water zones of retention ponds is vital to providing a $\mathrm{C}$ source to the soil. Thus, the width of littoral shelves containing this vegetation along the perimeter may be increased if $\mathrm{C}$ sequestration is a design goal. This assessment establishes that stormwater wet retention ponds can sequester $\mathrm{C}$ across 
different climate zones with generally annual rainfall and lengths of growing season being important general factors for $\mathrm{C}$ accumulation.

\section{Keywords}

Soil Carbon; Carbon Sequestration; Wet Retention Ponds; Climate Change; Stormwater Control Measures; Ecosystem Services

\section{Introduction}

The use of fossil fuels is the largest anthropogenic greenhouse gas source, and land use conversion (implicitly or through agricultural emissions) is the second leading contributor (IPCC, 2013). With C storage in biomass and soils becoming an increasingly valuable ecosystem service (Newell et al., 2013), policymakers have realized the need to mitigate climate change through better land use management (Lal, 2004). Globally, urban development continues to increase; by 2050, 2.3 billion new inhabitants will be living in urban areas (UN, 2010). This provides motivation to know how these new urban areas impact soil $\mathrm{C}$ and the global $\mathrm{C}$ budget.

This concept of ecosystem services has been utilized in environmental planning and management (De Groot, 2006) and is now extending to the design and management of stormwater infrastructure (Moore and Hunt, 2013; Kandulu et al., 2014). Runoff water quality and hydrology regulation remain the primary drivers for stormwater control measure (SCM) implementation and research, and accordingly, the primary metrics for evaluating performance (Lenhart and Hunt, 2011; Lucke and Nichols, 2015); however, as created ecosystems, SCMs can provide a variety of additional ecosystem services (Moore and Hunt, 2012). Accounting for these enables a more comprehensive estimation of the multifunctional values of SCMs. Given rising interest in and potential for regulation of $\mathrm{C}$ emissions, establishing $\mathrm{C}$ sequestration services of vegetated SCMs has become a recent research pursuit (Getter et al., 2009; Moore and Hunt, 2012; Bouchard et al., 2013). 
Constructed wet retention ponds (referred to as "ponds" hereafter) are engineered ecosystems designed to provide runoff hydrology and quality regulating services. Ponds can significantly reduce peak runoff rates, remove solids, and provide nitrogen and phosphorus removal (Hancock et al., 2010; Gallagher, 2011). Moore and Hunt (2012) also demonstrated the ability of ponds in North Carolina (humid subtropical climate), especially with a littoral shelf, to sequester C into the soil. Carbon sequestration could vary depending on ambient and climatic conditions; thus, the results of Moore and Hunt (2012) are not directly transferrable to other regions, which limits their relevance worldwide. This is important given ponds are one of the few SCMs used globally for stormwater management (Lundberg, et al., 1999; Vezzaro et al. 2011; Borne et al. 2013); yet, there has not been a global effort to quantify the $\mathrm{C}$ sequestration of these engineered ecosystems.

The goal of this study was to evaluate the soil $\mathrm{C}$ sequestration provided by wet retention ponds in four climate zones, with specific objectives to investigate the effects of design components (internal landforms and vegetation establishment) on $\mathrm{C}$ accumulation rates and making general, not statistical, comparisons of geographic effects (growing season, rainfall, temperature) these rates among the climate zones.

\section{Methods}

\subsection{Wet Retention Pond Design Characteristics}

Ponds are permanently wet basins that receive runoff from a watershed. Ponds are designed to have a permanent pool of water and additional capacity (typically $30 \mathrm{~cm}$ ) above the permanent pool to store and slowly release water volume from a design storm event (typically $25-40 \mathrm{~mm}$ ) over a period of two to five days. There are three different landforms (also known as hydrologic zones) in the pond: deep water, shallow water, and temporary inundation (Figure 1). The deep water and shallow water depths are measured from the permanent pool level and range from $30-$ 
$200 \mathrm{~cm}$ and $0-30 \mathrm{~cm}$, respectively (MDE, 2016; NCDEQ, 2016). The temporary inundation zone is an internal-to-pond floodplain and is designed for a maximum depth of (e.g.) $30 \mathrm{~cm}$ above the permanent pool level when a water quality event occurs. The temporary inundation zone has no significant standing water several days after the storm.

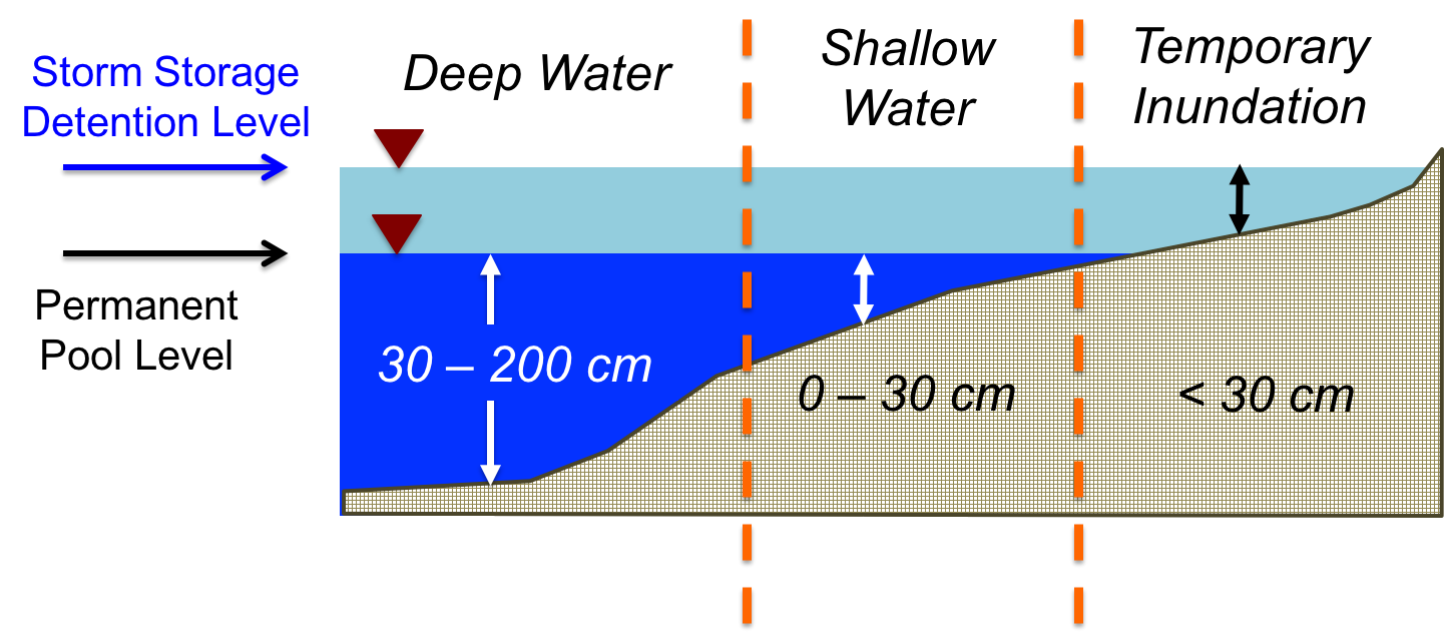

Figure 1: Cross section schematic of pond illustrating the three hydrologic zones: deep water, shallow water, and temporary inundation (schematic not to scale).

The deep water zone typically comprises most of the pond's surface area (approximately $90 \%$ coverage), leaving the remaining $10 \%$ divided between the shallow water and temporary inundation zones. Some ponds are designed with a littoral shelf, where shallow water and temporary inundation zones are purposely vegetated with emergent macrophytes. The littoral shelf is typically a 1-3-m wide perimeter around the pond (NCDEQ, 2016). This vegetation enhances pollutant removal (Knowles, 1982; Lenhart and Hunt, 2012), protects the shoreline from erosion (Zhou et al., 2008), and could contribute to volume losses due to evapotranspiration (Lott and Hunt, 2001).

\subsection{Study Sites}

Ponds were sampled in four different climate zones ( 
Figure 2): the United States, specifically in the state of North Carolina, (sub-humid, sub-tropical climate), Sweden (Southern Sweden - continental and Northern-subarctic climates), and Singapore (humid, tropical climate) (Peel et al., 2007). Moore and Hunt (2012) sampled 18 ponds, ranging from $2-15$ years of age, in North Carolina, USA. Ten of the surveyed ponds possessed a littoral shelf (Error! Reference source not found.). North Carolina has four distinct seasons, with average temperatures in December-February (winter) and June-August (summer) of $3.8^{\circ} \mathrm{C}$ and $25.6^{\circ} \mathrm{C}$, respectively (NCDC, 2014). The annual mean temperature is $15.3^{\circ} \mathrm{C}$, and annual rainfall is $1250 \mathrm{~mm}$ (NCDC, 2014). Precipitation is relatively well distributed throughout the year.

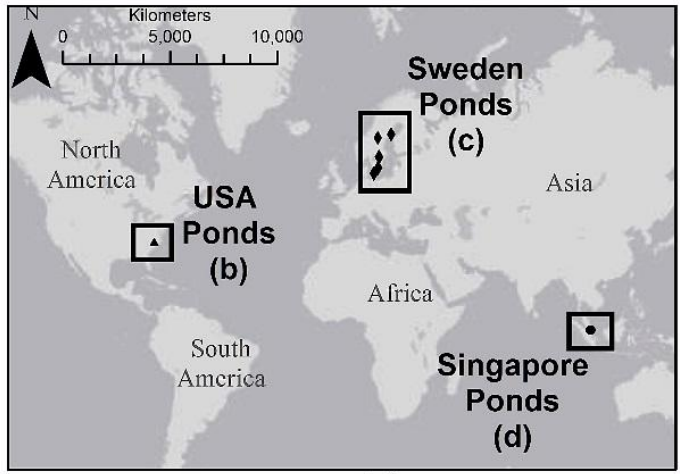

(a)

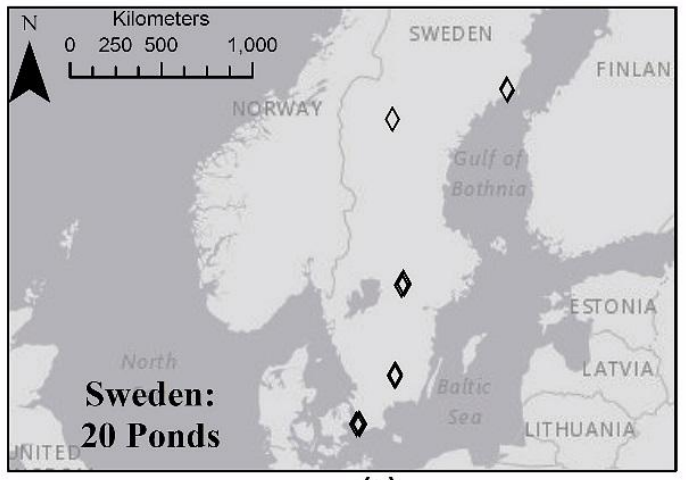

(c)

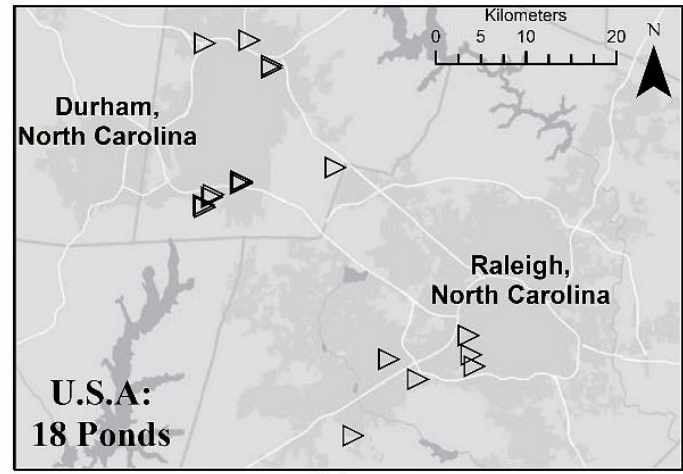

(b)

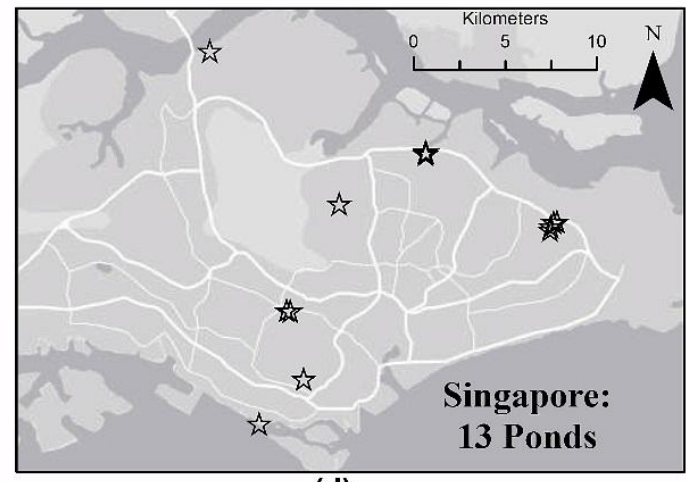

(d)

Figure 2: Ponds included in study: (a) global view of study areas, followed by detailed views of pond locations in (b) North Carolina (U.S.) (c) Sweden, and (d) Singapore. (Basemap: ESRI, 2015) 
Twenty ponds, $3-26$ years of age, were sampled in Sweden. All ponds examined had highly vegetated temporary inundation zones, but only eight possessed littoral shelves that extended into the shallow water zone (Error! Reference source not found.1). The sampling in Sweden crossed two different climate zones: humid continental and subarctic (Peel et al., 2007). The humid continental climate region of Sweden has a wide variation in average seasonal temperature, with December-February (winter) ranging from $-1^{\circ} \mathrm{C}$ to $2^{\circ} \mathrm{C}$ and June-August (summer) ranging from $14.5^{\circ} \mathrm{C}$ to $15.5^{\circ} \mathrm{C}$ (WWIS, 2014). Precipitation is relatively well distributed throughout the year with annual rainfall of approximately $600 \mathrm{~mm}$ (WWIS, 2014). The subarctic climate covers most of northern Sweden. Average seasonal temperatures for winter range from $-10^{\circ} \mathrm{C}$ to $-4^{\circ} \mathrm{C}$, with $13^{\circ} \mathrm{C}$ to $16^{\circ} \mathrm{C}$ in summer. The annual mean temperature of all Swedish sites sampled is $5.3^{\circ} \mathrm{C}$. Precipitation in this region is also well distributed with approximately $500 \mathrm{~mm}$ annually (WWIS, 2014). Furthermore, these climate zones also aligned with two different soil groups: arenosols (U.S. soil class: suborder of Entisol) in the southern areas and podsols (U.S. soil class: Spodosol) in the northern region. Therefore, the Swedish pond set was split into northern and southern regions for analyses (Error! Reference source not found.).

Thirteen ponds were sampled in Singapore ranging from 4 - 15 years of age (Error! Reference source not found.). Of the ponds surveyed, eight had a littoral shelf (Error! Reference source not found.). The ponds and associated catchment areas were all located within park lands managed by the National Parks Board of Singapore; therefore, the percent of impervious surfaces in the watersheds were nearly zero. This is considerably different than those sites sampled in USA and Northern and Southern Sweden. The inclusion of these sites is still valid because these ponds in Singapore do still receive relatively large amounts of stormwater runoff (annual rainfall 
$=2340 \mathrm{~mm}$ ). These National Parks are very well-groomed and function more as urban park areas compared to nature preserve areas where one could actually measure pre-development hydrology. These areas experience episodic events with flashy peak flows enough for the need of wet retention pond implementation throughout the country.

Singapore has a tropical rainforest climate with no distinctive (temperature) seasons, uniform mean daily temperatures $\left(26\right.$ to $38^{\circ} \mathrm{C}$, annual mean temperature of $26.7^{\circ} \mathrm{C}$ ), and abundant rainfall of $2340 \mathrm{~mm}$ annually (NEA, 2015; Peel et al., 2007). Rainfall is generally well-distributed throughout the year, peaking in December with the North-east Monsoon (NEA, 2015).

Utilizing a soil chronosequence, ponds of different ages were sampled in the different climate zones to calculate soil C accumulation rates. In its application, this "space for time substitution" method provides a convenient way to estimate $\mathrm{C}$ accumulation in the absence of long-term data sets (Neill et al., 1998; Golubiewski, 2006; Moore and Hunt, 2012; Bouchard et al., 2013).

However, in not measuring soil $\mathrm{C}$ accumulation rates directly, the authors note that the interpretation of chronosequence data is limited by the lack of supporting data, such as including inlet and outlet $\mathrm{C}$ flows and depositional patterns within each site. It is important to note GHG emissions were not measured or considered in this study. 
Table 1: Characteristics of Wet Detention Ponds Sampled

\begin{tabular}{|c|c|c|c|c|c|}
\hline $\begin{array}{c}\text { Climate } \\
\text { Zone }\end{array}$ & Site & $\begin{array}{c}\text { Age } \\
\text { (Years) }\end{array}$ & $\begin{array}{c}\text { Pond Area } \\
\text { (ha) }\end{array}$ & $\begin{array}{c}\text { Watershed } \\
\text { Area (ha) }\end{array}$ & $\begin{array}{l}\% \text { Watershed } \\
\text { Impervious }\end{array}$ \\
\hline \multirow{18}{*}{ USA } & US-1 & 2 & 0.17 & 5 & 85 \\
\hline & US-2* & 2 & 0.39 & 14 & 80 \\
\hline & US-3 & 4 & 0.12 & 4 & 52 \\
\hline & US-4 & 4 & 0.95 & 106 & 68 \\
\hline & US-5* & 4 & 0.24 & 27 & 50 \\
\hline & US-6* & 4 & 0.08 & 4 & 50 \\
\hline & US-7 & 5 & 0.2 & 7 & 32 \\
\hline & US-8* & 5 & 0.09 & 5 & 32 \\
\hline & US-9* & 6 & 0.05 & 3 & 54 \\
\hline & US-10 & 7 & 0.11 & 12 & 39 \\
\hline & US-11 & 7 & 1 & 100 & 82 \\
\hline & US-12* & 7 & 0.06 & 6 & 70 \\
\hline & US-13* & 7 & 0.08 & 9 & 80 \\
\hline & US-14* & 7 & 0.31 & 13 & 90 \\
\hline & US-15 & 9 & 0.14 & 3 & 65 \\
\hline & US-16* & 9 & 0.16 & 7 & 64 \\
\hline & US-17* & 9 & 0.05 & 7 & 70 \\
\hline & US-18 & 15 & 0.2 & 17 & 80 \\
\hline \multirow{9}{*}{$\begin{array}{l}\text { Northern } \\
\text { Sweden }\end{array}$} & SWE-1* & 3 & 2.21 & 1490 & 22 \\
\hline & SWE-4* & 6 & 0.33 & 30 & 5 \\
\hline & SWE-6* & 6 & 0.21 & 6 & 45 \\
\hline & SWE-7 & 7 & 0.5 & 30 & 80 \\
\hline & SWE-8 & 7 & 0.8 & 31 & 75 \\
\hline & SWE-11 & 7 & 0.75 & 55 & 75 \\
\hline & SWE-14 & 13 & 0.48 & 77 & 60 \\
\hline & SWE-15* & 13 & 0.45 & 84 & 97 \\
\hline & SWE-16* & 17 & 1.18 & 40 & 16 \\
\hline
\end{tabular}




\begin{tabular}{|c|c|c|c|c|c|}
\hline $\begin{array}{c}\text { Climate } \\
\text { Zone }\end{array}$ & Site & $\begin{array}{c}\text { Age } \\
\text { (Years) }\end{array}$ & $\begin{array}{c}\text { Pond Area } \\
\text { (ha) }\end{array}$ & $\begin{array}{c}\text { Watershed } \\
\text { Area (ha) }\end{array}$ & $\begin{array}{c}\% \text { Watershed } \\
\text { Impervious }\end{array}$ \\
\hline \multirow{11}{*}{$\begin{array}{l}\text { Southern } \\
\text { Sweden }\end{array}$} & SWE-2 & 3 & 0.13 & 89 & 85 \\
\hline & SWE-3* & 4 & 0.26 & 27 & 26 \\
\hline & SWE-5 & 6 & 0.35 & 69 & 60 \\
\hline & SWE-9 & 7 & 0.73 & 19 & 40 \\
\hline & SWE-10 & 7 & 0.16 & 13 & 69 \\
\hline & SWE-12 & 9 & 0.05 & 10 & 40 \\
\hline & SWE-13* & 12 & 1.89 & 342 & 95 \\
\hline & SWE-17 & 18 & 1.76 & 254 & 95 \\
\hline & SWE-18 & 19 & 1.8 & 320 & 80 \\
\hline & SWE-19* & 24 & 0.65 & 177 & 97 \\
\hline & SWE-20 & 26 & 0.09 & 130 & 10 \\
\hline \multirow{13}{*}{ Singapore } & SG-1 & 4 & 0.02 & 1.91 & 0 \\
\hline & SG-2 & 4 & 0.15 & 1.82 & 0 \\
\hline & SG-3 & 4 & 0.14 & 8.13 & 0 \\
\hline & SG-4 & 4 & 0.11 & 0.38 & 0 \\
\hline & SG-5* & 4 & 0.48 & 2.21 & 0 \\
\hline & SG-6* & 6 & 0.10 & 0.39 & 0 \\
\hline & SG-7* & 6 & 0.04 & 0.43 & 0 \\
\hline & SG-8* & 6 & 0.04 & 0.48 & 0 \\
\hline & SG-9* & 7 & 0.15 & 0.38 & 0 \\
\hline & SG-10* & 9 & 0.06 & 0.19 & 0 \\
\hline & SG-11 & 14 & 0.09 & 0.86 & 0 \\
\hline & SG-12* & 15 & 0.89 & 6.20 & 0 \\
\hline & SG-13* & 15 & 0.07 & 1.92 & 0 \\
\hline
\end{tabular}

*Pond possessed a littoral shelf. 


\subsection{Experimental Design and Sample Collection}

Experimental design and sampling collection protocol for ponds in Sweden and Singapore were adapted from Moore and Hunt (2012) (U.S. pond dataset) and Bouchard et al. (2013). At each pond, a total of nine soil samples were collected along three transects designated near the inlet, middle, and outlet of the pond (Figure 3). Wolf and Wagner (2005) found inundation depth to be a significant factor affecting $\mathrm{C}$ accumulation rates in ecosystems; therefore, transects were set perpendicular to the water flow path so that soil $\mathrm{C}$ samples could be collected from each of the three hydrologic zones in ponds (temporary inundation, shallow water, and deep water - Figure 1). At each sampling point, the upper $100 \mathrm{~mm}$ of the sediment profile was retrieved with a 50 $\mathrm{mm}$ diameter soil core. This sediment sampling depth was selected to capture where changes in wetland soil C content, and most likely pond soil $\mathrm{C}$ content, were expected to occur (Bruland and Richardson, 2006).

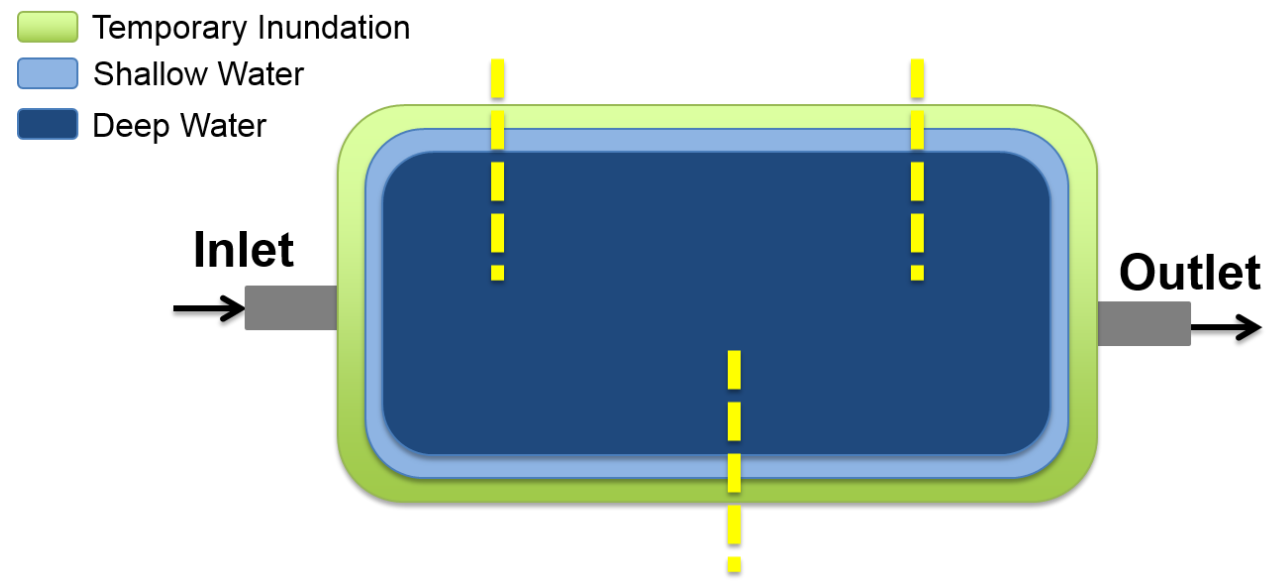

Figure 3: Plan view of pond with sampling transects

\subsection{Sample Collection and Analysis}

Bulk density measurements were performed on all individual cores for the Singapore and Sweden ponds. The cores were oven-dried at $105^{\circ} \mathrm{C}$ for a $36-48$ hour period and weighed 
(Blake and Hartge, 1986). The three bulk density measurements of the same hydrologic zone were averaged for each pond.

After individual core bulk densities were measured, a subsample from each core was pooled by hydrologic zone, subsequently ground to less than $250 \mu \mathrm{m}$, and analyzed for $\% \mathrm{C}$ (g C per g soil). Percent $\mathrm{C}$ was measured through dry combustion at $550^{\circ} \mathrm{C}$ with a Perkin-Elmer $2400 \mathrm{CHN}$ Elemental Analyzer (Golubiewski, 2006). To assume the total C from these analyses was equal to organic $\mathrm{C}$ content, the inorganic $\mathrm{C}$ component, primarily in the form of calcium carbonates, must be negligible (Buell and Makewich, 2004). As stated in Moore and Hunt (2012), soils throughout the North Carolina, USA, sampling region were generally acidic and classified as noncalcarous; therefore, inorganic $\mathrm{C}$ contribution by calcium carbonates was presumed negligible. The same can also be presumed for the soils sampled in Singapore, which is classified as having acidic, noncalcareous, and chemically poor soils (FAO, 1979). The sampling in Sweden took place in two different soil groups: Entisol in the southern areas and Spodosol in the northern region. Entisols are typically sandy-textured soils with poor nutrient content, low base cation concentrations such as calcium, and lack soil profile development (Brady and Weil, 2008). Spodosols are common in cold or temperate climates and are characterized as acidic soils and also have low base cation concentrations (Brady and Weil, 2008). The absence of calcium carbonates was confirmed for the sample areas through Swedish soil surveys (SFSI, 2015). The areal $\mathrm{C}$ density $\left(\mathrm{g} \mathrm{C} \mathrm{m}^{-2}\right.$ ) of each hydrologic zone (Eq. 1) was determined by multiplying the \% $\mathrm{C}$ soil content (g C per c soil) by the mean bulk density of the respective hydrologic zone $\left(\overline{\rho_{b}}\right)$ and the depth of the soil sample $\left(d_{\text {core }}=0.1 \mathrm{~m}\right)$ (Pouyat et al., 2009).

$$
\text { Areal C Density }=\% C * \overline{\rho_{b}} * d_{\text {core }}
$$


Because soil texture and structure affect $\mathrm{C}$ accumulation (Burke et al., 1989; Post and Kwon, 2000; Brady and Weil, 2008), subsamples of all cores from each pond were composited for particle size analysis using the hydrometer method (Gee and Bauder, 1986). Clay and silt proportions (\% Clay + Silt $)$ measured for each pond were used in the statistical analyses since fine particles have shown a direct relationship with \% C found in soils (Paul, 1984; Brady and Weil, 2008). The soil texture and subsequent \% Clay + Silt for the U.S. ponds were determined from NRCS soil surveys (NRCS, 2014).

\subsection{Statistical Analyses}

SAS 9.4 (C) statistical software was used to investigate the climate zone-specific parameter effects on the response variable, and areal $\mathrm{C}$ density. Due to physiographic, soil, and climate differences among the four climate zones, the statistical analyses were performed on the U.S., Northern Sweden, Southern Sweden, and Singapore datasets independently. A Generalized Linear Mixed Model (SAS 9.4 (C) PROC GLIMMIX Type III) was used to fit the datasets and make statistical inferences. This model permits the data to exhibit correlation and erratic variability and allows for a user-defined distribution. Due to evidence of heterogeneity of residual errors and right skew in the data, the lognormal distribution was used for these analyses. For each climate zone's analysis, the GLIMMIX model for the best fit was found by minimizing the residual mean error (ratio of Pearson Chi-Square Statistic and Degrees of Freedom) and visual inspection of the residual plots. A Pearson Chi-Square Statistic: Degrees of Freedom ratio of 1.00 indicated that the variability in these data had been properly modeled, and that there was no residual overdispersion. Significance was established at $\alpha=0.05$.

To examine potential rates of $\mathrm{C}$ accumulation in ponds, areal $\mathrm{C}$ densities, typically from each hydrologic zone, were regressed (SAS 9.4 (C PROC GLM) with statistically significant factors 
(age and/or \% Clay + Silt) found from the PROC GLIMMIX results. During this step, ponds with and without littoral vegetation were examined separately to approximate the relative factors affecting $\mathrm{C}$ accumulation. Prior to simple linear regression analyses, all data sets were checked (SAS 9.4 (C) PROC UNIVARIATE) and log-transformed if necessary to ensure that normality assumptions were met.

\section{Results}

\subsection{Average Soil Characteristics}

Table 2 contains the mean values and standard errors of site and soil physical conditions. Mean pond age for all sites examined was 7 years. Overall, soils had higher clay and silt contents in the U.S. and northern region of Sweden; sandier soils were observed in Singapore and southern Sweden.

Table 2: Sampled Site Characteristics (Mean \pm Standard Error)

\begin{tabular}{lccc}
\hline \multicolumn{1}{c}{ Climate Zone } & $\begin{array}{c}\text { Site Age } \\
(\text { Years })\end{array}$ & $\begin{array}{c}\text { Clay + Silt } \\
(\%)\end{array}$ & $\begin{array}{c}\text { Bulk Density } \\
\left(\mathrm{g} \mathrm{cm}^{-3}\right)\end{array}$ \\
\hline U.S. & $6.28 \pm 0.73$ & $58.7 \pm 3.0$ & $1.00 \pm 0.03$ \\
Sweden - North & $8.78 \pm 1.50$ & $68.6 \pm 6.8$ & $0.80 \pm 0.07$ \\
Sweden - South & $12.27 \pm 2.46$ & $18.9 \pm 3.5$ & $0.90 \pm 0.12$ \\
Singapore & $7.53 \pm 1.20$ & $26.2 \pm 3.9$ & $0.97 \pm 0.06$ \\
\hline
\end{tabular}




\subsection{Soil Areal C Density}

The mean areal $\mathrm{C}$ density ( \pm standard error) for the deep water, shallow water, and temporary inundation zones sampled in the humid subtropical region of the U.S. were $517.2 \pm 49.1 \mathrm{~g} \mathrm{C} \mathrm{m}^{-2}$, $502.6 \pm 49.2 \mathrm{~g} \mathrm{C} \mathrm{m}^{-2}$, and $1224 \pm 131.1 \mathrm{~g} \mathrm{C} \mathrm{m}^{-2}$, respectively (Figure 4). In contrast, the mean areal $\mathrm{C}$ density for the colder climate ponds in northern Sweden were higher overall with values of $1777 \pm 269 \mathrm{~g} \mathrm{C} \mathrm{m}^{-2}, 1649 \pm 454 \mathrm{~g} \mathrm{C} \mathrm{m}^{-2}$, and $1553 \pm 472 \mathrm{~g} \mathrm{C} \mathrm{m}^{-2}$ for the deep water, shallow water, and temporary inundation zones, respectively (Figure 4). Areal C densities for southern Sweden were the highest among the datasets - deep water: $2103 \pm 408 \mathrm{~g} \mathrm{C} \mathrm{m}^{-2}$, shallow water: $1779 \pm 365 \mathrm{~g} \mathrm{C} \mathrm{m}^{-2}$, and temporary inundation: $2283 \pm 259 \mathrm{~g} \mathrm{C} \mathrm{m}^{-2}$. The observed areal C densities for each hydrologic zone sampled in Singapore's tropical ponds were between those observed in the U.S. and Sweden: $1343 \pm 376 \mathrm{~g} \mathrm{C} \mathrm{m}^{-2}, 1341 \pm 334 \mathrm{~g} \mathrm{C} \mathrm{m}^{-2}$, and $1310 \pm 253 \mathrm{~g} \mathrm{C}$ $\mathrm{m}^{-2}$ for the deep water, shallow water, and temporary inundation zones, respectively (Figure 4).

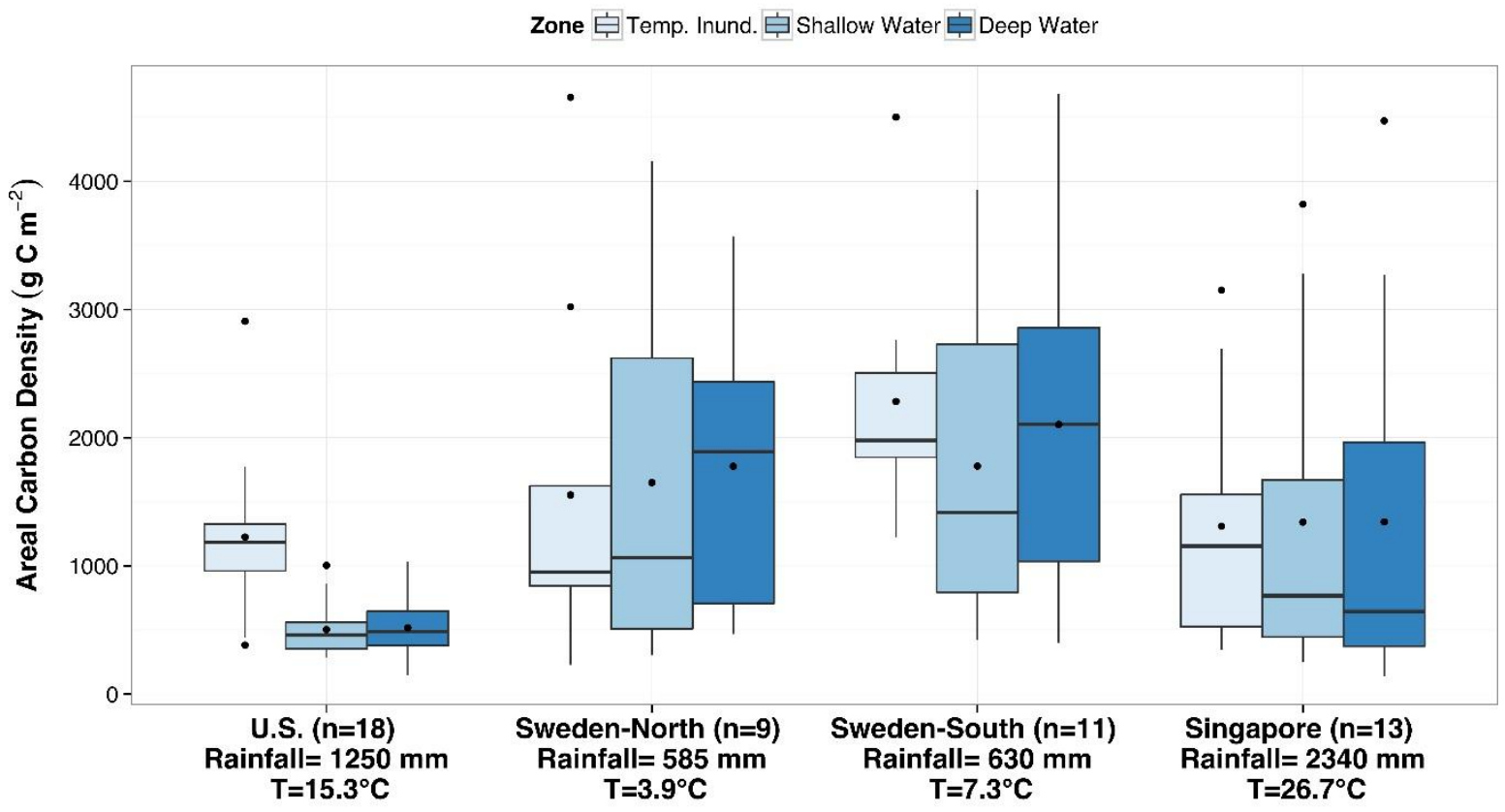

Figure 4: Areal C density of the top 100-mm of soil sampled in three different hydrologic zones (temporary inundation, shallow water, and deep water) of ponds in the U.S., northern Sweden, southern Sweden, and Singapore. 


\subsection{USA Ponds}

Because \% Clay + Silt is a possible factor in C sequestration rate, a new statistical analysis was conducted on the ponds sampled and originally presented in Moore and Hunt (2012). Figure 5 illustrates the GLIMMIX model fit of fixed effects and resultant $p$-values that best described the U.S. ponds' areal C density. This additive model of fixed effects listed on Figure 6 had a Pearson Chi-Square: Degrees of Freedom ratio of 1.38. The model indicated that vegetation status $(1=$ littoral shelf present, $0=$ no littoral shelf present: $p$-value $=0.012)$ and hydrologic zones $(p$ value $<0.0001$ ) were significant factors in $\mathrm{C}$ accumulation in U.S. ponds (Figure 5).

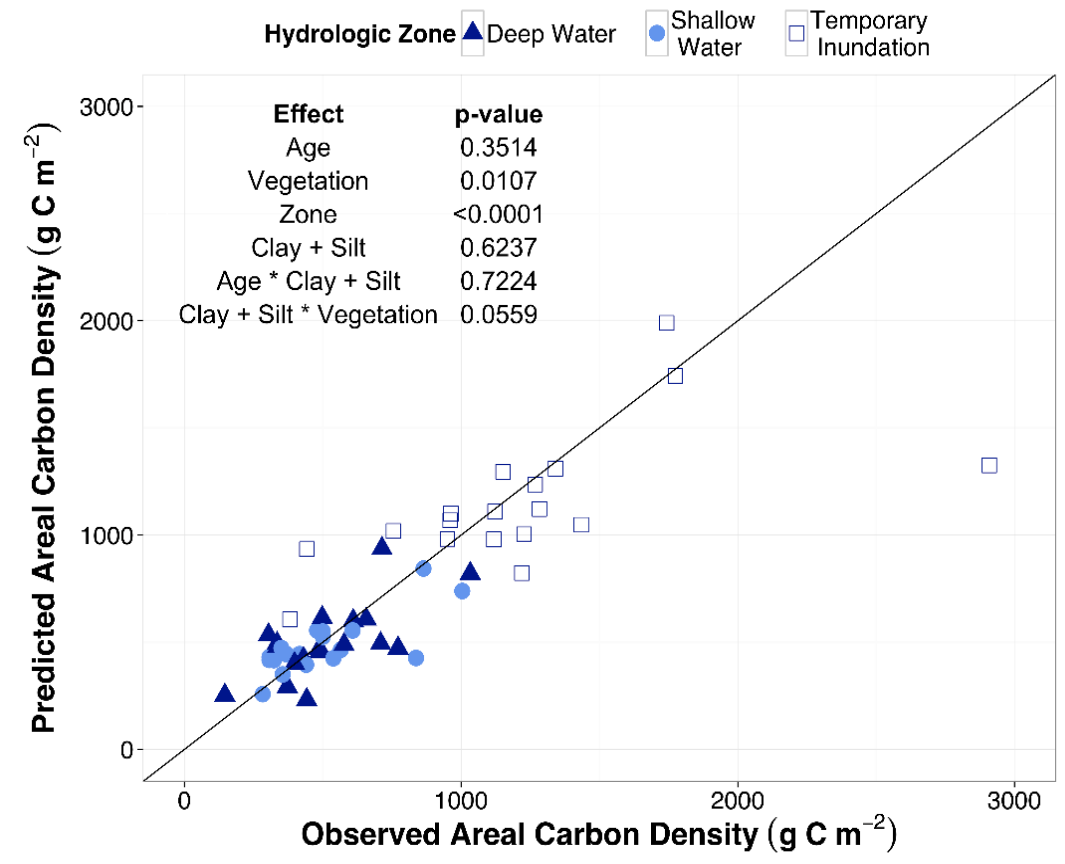

Figure 5: Observed vs. Predicted/Modeled values of areal C density with listed fixed effects investigated and associated $p$-values and

Since vegetation and hydrologic zone had significant roles in $\mathrm{C}$ accumulation, these factors were further investigated. The U.S. ponds with and without littoral vegetation were separated and regressed with age for each hydrologic zone. The overall areal C density of the shallow water 
zone of vegetated ponds (median $=532.5 \mathrm{~g} \mathrm{C} \mathrm{m}^{-2}$ ) was significantly greater than that of nonvegetated ponds (median $=362.5 \mathrm{~g} \mathrm{C} \mathrm{m}^{-2}$; Wilcoxon rank sum $p$-value $\left.=0.0328\right)$. The predicted rate of soil $\mathrm{C}$ accumulation with age (78.43 $\left.\mathrm{g} \mathrm{C} \mathrm{m}^{-2} \mathrm{yr}^{-1}\right)$ in vegetated zones of U.S. ponds was significant $($ PROC GLM $p$-value $=0.0104$ ). Linear regression showed no significant effect of \% Clay + Silt on C accumulation (PROC GLM, $p$-value $=0.112)$. These results were in line with those found in the analysis of Moore and Hunt (2012).

\subsection{Sweden Ponds}

The GLIMMIX model fit of fixed effects (Pearson Chi-Square:Degrees of Freedom ratio) for ponds in northern Sweden was 3.89 (Figure 6a) and revealed \% Clay + Silt and Hydrologic Zone to have significant effects on areal $\mathrm{C}$ density. Clay + Silt percentage also was found to significantly affect C accumulation (Figure 6b) in southern Sweden (Pearson ChiSquare:Degrees of Freedom ratio $=2.00)$. Linear regression of $\mathrm{C}$ density with the $\%$ Clay + Silt was conducted for both regions; no relationship was found for ponds located in the northern region, but a positive relationship, albeit weak, between $\mathrm{C}$ densities and \% Clay + Silt for the southern ponds was observed $($ PROC GLM: Carbon $=76.68($ Clay + Silt $)+445.21, p$-value $=$ 0.0004Error! Reference source not found.). 


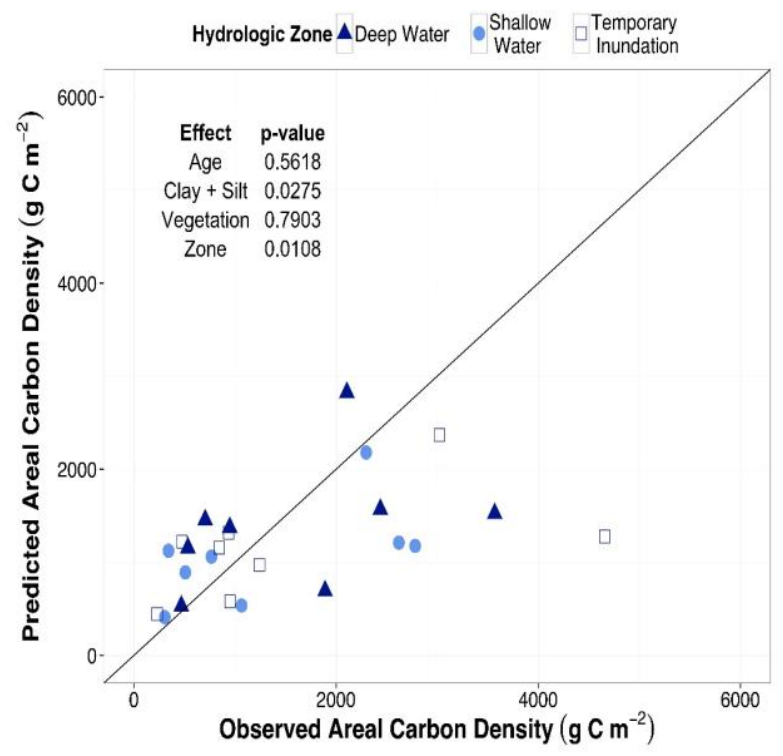

(a)

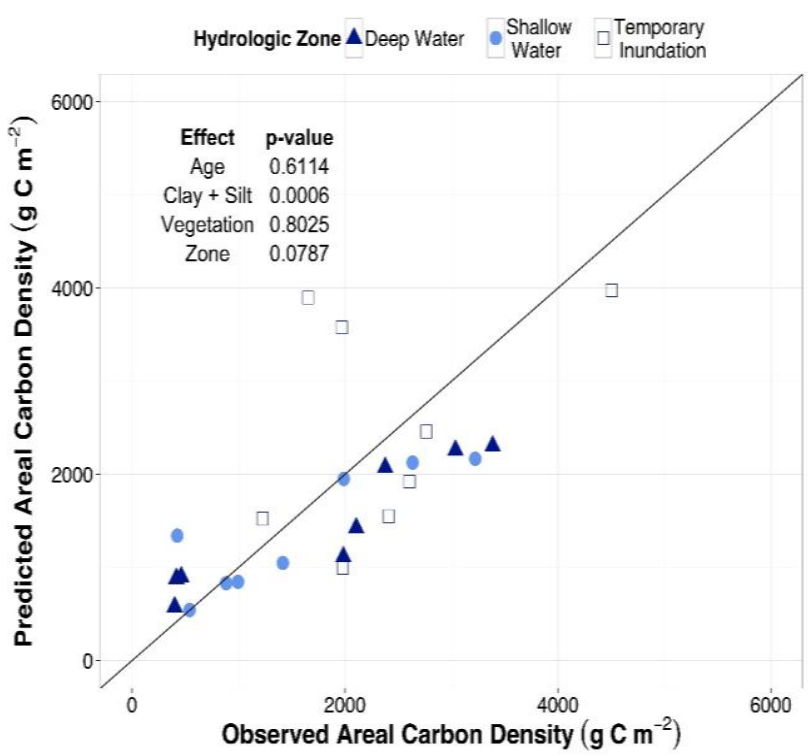

(b)

Figure 6: Observed vs. Predicted/Modeled areal C density with listed fixed effects investigated for the ponds sampled in (a) northern Sweden and (b) southern Sweden and associated $p$-values.

All the Swedish ponds (north and south) had highly vegetated temporary inundation zones at the time of sampling, but not all littoral vegetation extended into the shallow water zones (that is, they did not have littoral shelves, per se) as indicated in Error! Reference source not found.. Because the USA results demonstrated a significant $\mathrm{C}$ accumulation with age in the vegetated shallow water areas of ponds, vegetated zones for all Swedish ponds were lumped together and investigated. The ponds with and without littoral shelves were separated and regressed with age for each hydrologic zone. Although not significant at the $\alpha=0.05$ level (PROC GLM: Carbon $=$ $75.81($ Age $)+1143.2 ; p$-value $=0.0510)$, the temporary inundation zone trended toward $\mathrm{C}$ accumulation $\left(75.81 \mathrm{~g} \mathrm{C} \mathrm{m}^{-2} \mathrm{yr}^{-1}\right)$ with age. Soil texture (\% Clay + Silt $)$ was the main $\mathrm{C}$ accumulation factor in both Swedish regions, in addition to pond age, when examining vegetated temporary inundation zones of all Swedish ponds. 


\section{Singapore Ponds}

Figure 7 illustrates the GLIMMIX model fit of the listed fixed effects and resultant $p$-values that best described the Singapore ponds' areal C density values. This model had a Pearson ChiSquare:Degrees of Freedom ratio of 1.95. The model indicated that age was the significant factor $(p$-value $=0.0016)$ in $\mathrm{C}$ accumulation.

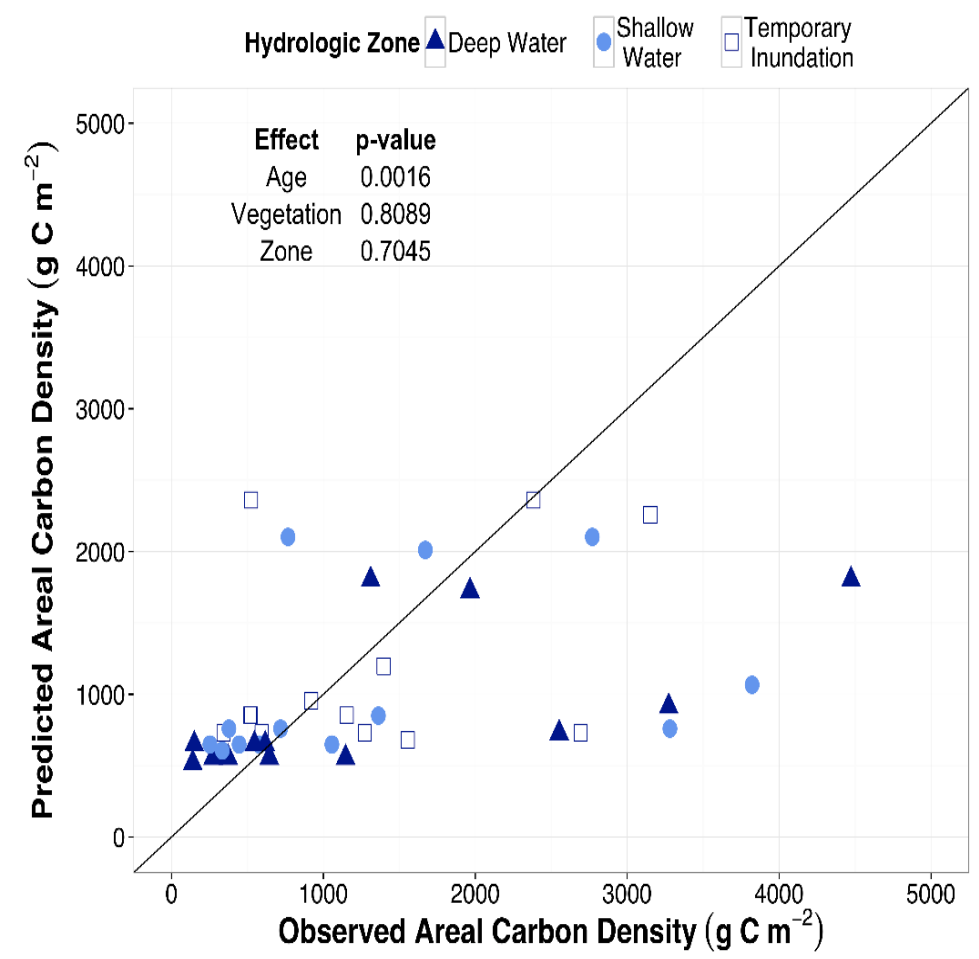

Figure 7: Observed vs. Predicted/Modeled values of areal $\mathrm{C}$ density with listed fixed effects investigated and associated $p$-values

Since hydrologic zone and vegetation status ( 8 of 13 ponds possessed littoral shelves) did not affect $\mathrm{C}$ accumulation, areal $\mathrm{C}$ densities for all ponds and hydrologic zones were regressed with age to determine a $\mathrm{C}$ accumulation rate. The rate of soil $\mathrm{C}$ accumulation with age $\left(135.24 \mathrm{~g} \mathrm{C} \mathrm{m}^{-}\right.$ ${ }^{2} \mathrm{yr}^{-1}$ ) of ponds in Singapore was significant (PROC GLM: Carbon $=135.2($ Age $)+311.89, p$ value $=0.0012$ ). However, only $25 \%$ of the variability in areal carbon densities was explained by pond age $\left(R^{2}=0.25\right)$. 


\section{Discussion of Carbon Accumulation Factors}

When investigating vegetated pond zones utilizing the chronosequence experimental design, age was found to be a significant predictor for areal $\mathrm{C}$ densities in all four climate zones, demonstrating that certain parts of ponds can accumulate $\mathrm{C}$ over time. Because these $\mathrm{C}$ accumulation rates were determined independently among climate zones, comparisons made and discussed hereafter were not based on statistical analyses; they are mere generalizations of C accumulation factors and mechanics. Carbon accumulation rates for vegetated shallow water areas in U.S. ponds (78.4 $\left.\mathrm{g} \mathrm{C} \mathrm{m}^{-2} \mathrm{yr}^{-1}\right)$, temporary inundation zones in Sweden $\left(75.8 \mathrm{~g} \mathrm{C} \mathrm{m}^{-2} \mathrm{yr}^{-}\right.$ ${ }^{1}$ ), and throughout all hydrologic zones of ponds in Singapore $\left(135 \mathrm{~g} \mathrm{C} \mathrm{m}^{-2} \mathrm{yr}^{-1}\right)$ were similar to other estimates by researchers. Moore and Hunt (2012) found vegetated shallow water areas of constructed stormwater wetlands in North Carolina, USA, to sequester $\mathrm{C}$ at a rate of $84.4 \mathrm{~g} \mathrm{C} \mathrm{m}^{-2}$ $\mathrm{yr}^{-1}$. Two riverine wetlands accumulated organic $\mathrm{C}$ accumulation at rates of $152-166 \mathrm{~g} \mathrm{C} \mathrm{m}^{-2} \mathrm{yr}^{-}$ ${ }^{1}$ over a 10-year period in Ohio, USA (Anderson and Mitsch, 2006). The soil organic C accumulation rate in created estuarine marshes in North Carolina, USA, was $80 \mathrm{~g} \mathrm{C} \mathrm{m}^{-2} \mathrm{yr}^{-1}$ (Craft, 1997). The observed rates of $\mathrm{C}$ accumulation in all four climate zones were also comparable to that of other stormwater control measures and land uses. Bouchard et al. (2013) found a $\mathrm{C}$ accumulation rate of $99 \mathrm{~g} \mathrm{C} \mathrm{m}^{-2} \mathrm{yr}^{-1}$ in roadside vegetated filter strips and vegetated swales in the piedmont region of North Carolina, and U.S. residential turf grasses have been shown to sequester $\mathrm{C}$ at rates of $72-90 \mathrm{~g} \mathrm{C} \mathrm{m}^{-2} \mathrm{yr}^{-1}$ (Qian and Follett, 2002; Golubiewski, 2006; Pouyat et al. 2009). Soils of grasslands and forests reestablished on formerly cultivated lands were found to accumulate $54-80 \mathrm{~g} \mathrm{C} \mathrm{m}^{-2} \mathrm{yr}^{-1}$ (Conant et al., 2001; Riedell et al., 2011). At some point these land uses will most likely reach a "saturation age" where rates of $\mathrm{C}$ accumulation will slow or cease (Post and Kwon, 2000). Bouchard et al. (2013) found that after 21.5 years, 
roadside vegetated swales and filter strips no longer sequestered C. Additionally, West et al. (2004) found that land converted to grassland accumulated $\mathrm{C}$ at a higher rate $\left(74 \mathrm{~g} \mathrm{C} \mathrm{m}^{-2} \mathrm{yr}^{-1}\right)$ within the initial 15 years, as compared to slower rates (65 and $54 \mathrm{~g} \mathrm{C} \mathrm{m}^{-2} \mathrm{yr}^{-1}$ ) at 15-30 and 3045 years, respectively. There was no evidence of $\mathrm{C}$ saturation herein with age; however, these ponds were also fairly young (age $<26$ years). To investigate the time to "C saturation" of ponds, the age range of ponds must be expanded in future studies.

The presence of vegetation (with age) was significant for $\mathrm{C}$ accumulation for shallow water zones in the USA ponds and temporarily inundated zones in Sweden. The presence of water in permanently flooded sites (shallow and deep water zones) slows organic matter decomposition due to anaerobiosis; whereas, in temporarily inundated zones, a substantial portion of the $\mathrm{C}$ that is initially retained in the soil during flooding is later oxidized when this zone dries (Wolf and Wagner, 2005). Bernal and Mitsch (2008) suggested that the presence of continuous anaerobic conditions is the more important factor for enhancing $\mathrm{C}$ storage in wetland soils than higher productivity of vegetation in temperate and tropical climates. This explains why the shallow water zones (which remain saturated by design), not temporary inundation zones (which do not), demonstrated $\mathrm{C}$ accumulation in the USA ponds with a temperate climate. However, Swedish ponds had a different result, as stated previously. Bernal and Mitsch (2008) further state that it is the combination of both anaerobic conditions and ecosystem productivity that make permanently flooded wetland soils highly organic. Sweden has a colder climate (and thus lower decomposition rates) relative to the USA; because of the climate, temporarily inundated areas were much better vegetated than shallow water zones (a direct contract to the USA). C accumulation rates reflected vegetated coverage. Given the lack of $\mathrm{C}$ accumulation with age observed in non-vegetated ponds in both Sweden and the USA, it is speculated that biomass 
produced internally, rather than inputs from external sources in watersheds, leads to pond C accumulation. Biomass carbon of emergent and submerged vegetation were not directly measured in this study because soil $\mathrm{C}$ measurements were assumed to be indicative of permanently sequestered $\mathrm{C}$, whereas biomass $\mathrm{C}$ can be mobile and/or oxidized (Wolf and Wagner, 2005).

The ponds sampled in Singapore also demonstrated an accumulation of $\mathrm{C}$ with age, regardless of hydrologic zone or presence of littoral vegetation, which could be attributed to proliferation of algal biomass in nearly all of the Singaporean ponds. As the algae die, $\mathrm{C}$ is accumulated at the bottom of the ponds, and the majority of the algal biomass $\mathrm{C}$ stay sequestered long term (Arfi and Guiral, 1994). Moore and Hunt (2012) highlighted the importance of vegetation in C accumulation for constructed stormwater wetlands in the urban environment, while Craft et al. (1988) found that vegetation was also the primary soil C source in constructed coastal marshes. The importance of vegetation is highlighted as a key factor in soil organic $\mathrm{C}$ accumulation in shrublands, grasslands, and forests for many different climates in Jobbágy and Jackson (2000).

Others have documented substantially higher rates of $\mathrm{C}$ accumulation in ponds. Downing et al. (2008) estimated $\mathrm{C}$ burial rates in eutrophic agricultural ponds could exceed $10,000 \mathrm{~g} \mathrm{~m}^{-2} \mathrm{yr}^{-1}$. Anderson and Mitsch (2006) observed greater organic C density and accumulation rates in the deep water regions of two constructed wetlands compared to shallow water zones with emergent vegetation, primarily due to the higher mean sediment accumulation observed in deep water zones compared to the rest of the wetlands. Although not measured directly herein, contributions of $\mathrm{C}$ from the contributing watersheds is likely small as sedimentation rates from stabilized urban areas range from 0.1 to $13 \mathrm{~kg} \mathrm{~m}^{-2} \mathrm{yr}^{-1}$ (Walker, 2001; Graney and Eriksen, 2004; Pontier et al., 2004). Moreover, the muck layer observed in the ponds during sampling was neither sediment- 
filled nor deep, supporting the postulation that sedimentation rates and $\mathrm{C}$ additions from contributing watersheds were relatively low. The areal C density values, herein, among the three hydrologic zones in both Singapore and Sweden were not significantly different (Tukey-Kramer: all $p$-values > 0.18). For the U.S. ponds, the $\mathrm{C}$ densities for deep and shallow water zones were not significantly different $($ Tukey-Kramer $p$-value $=0.99)$. The lack of difference in C content among the hydrologic zones may suggest the assessing technique is limited when detecting site level trends in organic $\mathrm{C}$ distribution. While the method uncovered differences in accumulation patterns between vegetated and non-vegetated sites, it was too coarse to detect the spatial distribution of $\mathrm{C}$ within a site. Finer resolution sampling designs, similar to Anderson et al. (2005), Anderson and Mitsch (2006), and Drouin et al. (2011), could be utilized to uncover depositional patterns of $\mathrm{C}$ in ponds. These finer resolution methods could also provide more detailed investigations spatial distribution of $\mathrm{C}$ within a pond and hydrodynamic factors affecting $\mathrm{C}$ accumulation, specifically in the temporary inundation zone to compare the magnitudes of soil $\mathrm{C}$ input from vegetation versus increased deposition of external $\mathrm{C}$ inputs due to reduced flow velocities.

Clay can protect soil organic matter from decomposition by adsorption and aggregation, slowing turnover, thereby effectively increasing soil organic matter (Paul, 1984; Burke et al., 1989; Torn et al., 1997). Increasing silt content also increases water holding capacity, impacting water availability, an important factor for plant productivity (and resultant soil C inputs, Paul, 1984; Burke et al., 1989; Jobbágy and Jackson, 2000). In this study, the influence of \% Clay + Silt content on $\mathrm{C}$ accumulation was observed in drier environments (Sweden) and diminished as annual precipitation and temperature increased; \% Clay + Silt did not explain any of the variation of C accumulation in U.S. and Singapore ponds. 
The ponds measured in each of the four climate zones have differing spatial extents: ponds in USA and Singapore were closer together, spatially, than those ponds sampled in northern and southern Sweden. However, some of the observed variability might instead be due to design guidance differences among the four climatic zones. For instance, the USA ponds were relatively well modeled (Pearson Chi-Square: Degrees of Freedom ratio of 1.38), while the Singapore (1.95), northern Sweden (3.89), southern Sweden (2.00) were not fit as well, despite best efforts. The USA ponds were all designed under the same design manual and guidance (NCDEQ, 2016), while no uniform design guidance was found for wet retention pond design in Sweden (northern or southern) or Singapore.

Soil organic $\mathrm{C}$ storage is the balance of $\mathrm{C}$ inputs from plant production and outputs through decomposition (Schlesinger, 1977; Burke et al., 1989; Jobbágy and Jackson, 2000). In humid climates, both production and decomposition rates of vegetation increase with temperature (Schlesinger, 1977; Oades, 1988), but previous research established increases in decomposition are greater, creating an overall indirect relationship between $\mathrm{C}$ accumulation and temperature (Schlesinger, 1977; Oades, 1988; Burke et al., 1989). Based on temperature (and associated decomposition rates) alone, one would expect rates of $\mathrm{C}$ accumulation to be greatest in Sweden and least in Singapore, but as demonstrated herein, this was not the case. The annual rainfall amounts and approximate lengths of the growing season in the sampling regions of Sweden (600 mm, 120 days), USA (1250 mm, 200 days), and Singapore (2340 mm, 365 days) span a wide range (NCDC, 2014; WWIS, 2014; NEA, 2015). In arid to subhumid ecosystems, annual rainfall is the most-limiting factor in production and subsequent decomposition of plants (Webb et al., 1978; Sala et al., 1988; Amundson et al., 1989). Higher rainfall and lengths of growing season in these ecosystems yielded a greater response of plant production relative to decomposition rates 
(Webb et al., 1978; Sala et al., 1988; Amundson et al., 1989; Burke et al., 1989; Austin and Vitousek, 1998). Therefore, from annual rainfall and lengths of growing season alone (plant production), rates of $\mathrm{C}$ accumulation would be greatest in Singapore and least in Sweden. Ideal conditions for $\mathrm{C}$ sequestration are when plant production is maximized (high rainfall and growing season days) and decomposition rates are minimized (lower temperature). How these two $\mathrm{C}$ accumulation mechanisms (rainfall/growing season and temperature) compete was demonstrated; accumulation rates in vegetated areas of ponds in the U.S. and Sweden were very similar: 78.4 and $75.8 \mathrm{~g} \mathrm{C} \mathrm{m}^{-2} \mathrm{yr}^{-1}$, respectively, while those of Singapore were almost double: $135 \mathrm{~g} \mathrm{C} \mathrm{m}^{-2} \mathrm{yr}^{-1}$. Despite Singapore's relatively high mean annual temperature relative to that of the U.S. and Sweden, it appears that high annual rainfall and year-round growing season promote more plant production and subsequent $\mathrm{C}$ input to the soil, 'overwhelming' decomposition rates. Meanwhile, low plant production but slow decomposition rates in Sweden yielded the same C accumulation rate observed in the USA, which had higher decomposition rates but also more rainfall and a longer growing season (and presumably more $\mathrm{C}$ inputs to the soil. Annual rainfall, or lack thereof, was distinguished as an important $\mathrm{C}$ accumulation factor. Future research should focus on the role of annual rainfall and growing season lengths on $\mathrm{C}$ accumulation in ponds. Future research endeavors are also needed to quantify GHG fluxes in wet retention ponds to better understand the net carbon sequestration rate in these aquatic ecosystems.

\subsection{Design Implications for Carbon Accumulation in Ponds}

The $\mathrm{C}$ accumulation assessment of ponds herein suggests that littoral vegetation is a significant source for the soil $\mathrm{C}$ pool relative to $\mathrm{C}$ sources from the contributing watersheds; it is a critical component of C sequestration in ponds. Moore and Hunt (2012) found that vegetated shallow water areas of constructed stormwater wetlands were able to sequester $\mathrm{C}$ at rates of $84.4 \mathrm{~g} \mathrm{C} \mathrm{m}^{-2}$ 
$\mathrm{yr}^{-1}$, while Craft et al. (1999) observed accumulation rates of 90-160 $\mathrm{g} \mathrm{C} \mathrm{m}^{-2} \mathrm{yr}^{-1}$ in coastal North Carolina, USA, marshes. Establishing vegetation in the shallow water and temporary inundation zones of ponds is vital to providing a $\mathrm{C}$ source to the soil. Current design guidance (MDE, 2016; NCDEQ, 2016) suggests the littoral shelf surface coverage be limited to 1 to $3 \mathrm{~m}$ wide swaths around the perimeter of the pond. If $\mathrm{C}$ sequestration is a design goal, perhaps the width of this shelf should be increased. Ensuring the water levels are suitably shallow to support emergent vegetation is also important. This can be achieved by adjustable outlet structures and proper maintenance (Hunt et al., 2011; Merriman and Hunt, 2014). A soil test is recommended to assure sufficient soil nutrients for healthy vegetation growth while minimizing the potential for nutrient export.

\section{Summary and Conclusions}

The carbon sequestration services of stormwater wet retention ponds were investigated in four different climates in the USA, Sweden, and Singapore, representing a range of annual mean temperatures and rainfall amounts. The three pond landforms (hydrologic zones) - deep water, shallow water, and temporary inundation - were assessed, with the presence of littoral vegetation noted during sample collection.

The competing potential mechanisms of vegetation production (Singapore $>$ U.S. $>$ Sweden) and decomposition rates (Singapore > U.S. > Sweden) on C accumulation rates are evident in this study. Accumulation rates found for vegetated areas of ponds in the USA and Sweden were very similar: 78.4 and $75.8 \mathrm{~g} \mathrm{C} \mathrm{m}^{-2} \mathrm{yr}^{-1}$, respectively, while rates of $\mathrm{C}$ accumulation in Singapore were almost double: $135 \mathrm{~g} \mathrm{C} \mathrm{m}^{-2} \mathrm{yr}^{-1}$. Although Singapore has a relatively high mean annual temperature relative to the USA and Sweden, high annual rainfall amounts and a year-round growing season enable more plant production and subsequent $\mathrm{C}$ sources to the soil, apparently 
'overwhelming' decomposition rates. Meanwhile, low primary production but slow decomposition rates in Sweden yielded the same $\mathrm{C}$ accumulation rate observed in the U.S., with the latter's higher decomposition rates offset by higher rainfall and a longer growing season for C inputs to the soil.

Littoral vegetation was a significant source to the soil C pool relative to watershed C sources and a critical component of $\mathrm{C}$ sequestration in these systems. Establishing vegetation in the shallow water and temporary inundation zones of retention ponds appears vital to providing a long-term C source to the soil. Increasing the typically limited coverage of littoral vegetation (that provided by a 1-3 $\mathrm{m}$ strip of perimeter vegetation) is recommended if $\mathrm{C}$ sequestration is a design goal. Ensuring sufficiently shallow water levels to support emergent vegetation is important.

While more detailed analysis is recommended to better understand inlet $\mathrm{C}$ sources, spatial distribution of $\mathrm{C}$ within a pond, hydrodynamic factors affecting $\mathrm{C}$ accumulation, and the net $\mathrm{C}$ sequestration benefit considering GHG emissions, this assessment using a chronosequence experimental design establishes that vegetated stormwater wet retention ponds have the ability to sequester $\mathrm{C}$ over time in four different climate zones, with texture $(\%$ Clay + Silt content) being an additional significant factor in $\mathrm{C}$ accumulation in some systems. Annual rainfall, or lack thereof, combined with growing season lengths were distinguished as important $\mathrm{C}$ accumulation factors. Gaining insights into the effect of decomposition rates on $\mathrm{C}$ accumulation across climates with similar annual rainfall and growing season lengths will be valuable.

\section{Acknowledgements}

The authors would like to thank Dr. Consuello Arellano, North Carolina State University (NCSU) Department of Statistics, for her assistance with the statistical analyses, Dr. Matthew Polizzotto, NCSU Soils Science Department, for logistical assistance in shipping soil samples, 
and Lisa Lentz, NCSU Environmental and Agricultural Testing Service, for soil sample analyses.

The authors also thank the U.S. National Science Foundation, the North Carolina Department of Natural Resources - Ecosystem Enhancement Program, VINNOVA: Swedish Governmental Agency for Innovation Systems, and Joint Programming Initiative Urban Europe for the financial support this study. The authors would also like to acknowledge the staff at the Swedish Municipalities (Örebro, Östersund, Växjö, Malmö, and Umeå) and the staff of the Singapore National Parks Board for their assistance.

\section{References}

Amundson, R.G., Chadwick, O.A., Sowers, J.M. 1989. A comparison of soil climate and biological activity along an elevation gradient in the eastern Mojave Desert. Oecologia, 80: 395400 .

Anderson, C.J. and Mitsch, W.J. 2006. Sediment, carbon, and nutrient accumulation at two 10year-old created riverine marshes. Wetlands, 26: 779-792.

Anderson, C.J., Mitsch, W.J., and Nairn, R.W. 2005. Temporal and spatial development of surface soil conditions at two created riverine marshes. Journal of Environmental Quality, 34: 2072-2081.

Arfi, R. and Guiral, D. 1994. Chlorophyll budget in a productive tropical pond: algal production, sedimentation, and grazing by microzooplankton and rotifers. Hydrobiologia, 272(1): 239-249.

Austin, A.T. and Vitousek, P.M. 1998. Nutrient dynamics on a rainfall gradient in Hawaii. Oecologia, 113: 519-529.

Bernal, B. Mitsch. W.J. 2008. A comparison of soil carbon pools and profiles in wetlands in Costa Rica and Ohio. Ecological Engineering, 34(4): 311-323.

Blake, G.R., Hartage, K.R. 1986. Bulk density. In: Klute, A. (Ed.), Methods of Soil Analysis Part 1: Physical and Mineralogical Methods $2^{\text {nd }}$ Edition. Soil Science Society of America, Madison, WI. pp. 363-375.

Borne, K.E., Fassman, E.A., Tanner, C.C. 2013. Stormwater nitrogen removal performance of a floating treatment wetland. Water Science and Technology, 68(7): 1657-1664.

Bouchard, N.R., Osmond, D.L., Winston, R.J., Hunt, W.F. 2013. The capacity of roadside vegetated filter strips and swales to sequester carbon. Ecological Engineering, 54: 227-232. 
Brady, N.C. Weil, R.R. 2008. The Nature and Property of Soils. $14^{\text {th }}$ Edition. Pearson Education Inc. New Jersey.

Bruland, G.L., Richardson, C.J. 2006. Comparison of soil organic matter in created, restored, and paired natural wetlands in North Carolina. Wetlands Ecology and Management, 14: 245-251.

Buell, G.R., Makewich, H.W. 2004. Data compilation, synthesis, and calculations used for organic-carbon storage and inventory estimates for mineral soils of the Mississippi River Basin. In: Makewich, H.W. (Ed.), Soil-Carbon Storage and Inventory for the Continental United States. U.S. Geological Survey, Reston, VA.

Burke, I.C., Yonker, C.M., Parton, W.J., Cole, C.V., Flach, K., Schimel, D.S. 1989. Texture, climate, and cultivation effects on soil organic matter content in U.S. grassland soils. Soil Science Society of America Journal, 53: 800-805.

Conant, R.T., Paustian, K., Elliott, E.T. 2001. Grassland management and conversion into grassland: effects on soil carbon. Ecological Applications, 11(2): 343-355.

Costanza, R., d'Arge, R., de Groot, R., Farber, S., Grasso, M., Hannon, B., Limberg, K., Naeem, S., O’Neill, R., Paruelo, J., Raskin, R., Sutton, P., van den Belt, M. 1997. The value of the world's ecosystem services and natural capital. Nature, 387: 253-260.

Craft, C.B. 1997. Dynamics of nitrogen and phosphorus retention during wetland ecosystem succession. Wetlands Ecology and Management, 4: 177-187.

Craft, C.B., Broome, S.W., Seneca, E.D., Showers, W.J. 1988. Estimating sources of soil organic matter in natural and transplanted estuarine marshes using stable isotopes of carbon and nitrogen. Estuarine, Coastal and Shelf Science, 26: 633-641.

Craft, C.B., Reader, J., Sacco, J.N., Broome, S.W. 1999. Twenty-five years of ecosystem development of constructed Spartina alterniflora (Loisel) marshes. Ecological Applications, 9(4): 1405-1419.

De Groot, R. 2006. Function-analysis and valuation as a tool to assess land use conflicts in planning for sustainable, multi-functional landscapes. Landscape Urban Planning. 75: 175-186.

Downing, J.A., Cole, J.J., Middelburg, J.J., Stiegl, R.G., Duarte, C.M., Kortelainen, P., Praire, Y.T., Laube, K.A. 2008. Sediment organic carbon burial in agricultural eutrophic impoundments ove the last century. Global Biogeochemical Cycles, 22: GB1018, doi:10.1029/2006GB002854

Drouin, A., Saint-Laurent, D., Lavoie, L., and Ouellet, C. 2011. High-precision elevation model to evaluate the spatial distribution of soil organic carbon in active floodplains. Wetlands, 31(6): 1151-1164.

ESRI. 2015. World Light Gray Base Map. http://services.arcgisonline.com/ArcGIS/rest/services/Canvas/World_Light_Gray_Base/MapServ er Assessed: 11 June 2015. 
Food and Agricultural Organization of the United Nations (FAO). 1979. Soil Map of the World. Volume IX: Southeast Asia. Published by United Nations Educational, Scientific, and Cultural Organization (UNESCO). Paris, France.

Gallagher, M.T., Snodgrass, J.W., Ownby, D.R., Brand, A.B., Casey, R.E., Lev, S. 2011. Watershed-scale analysis of pollutant distributions in stormwater management ponds. Urban Ecology, 14: 469-484.

Gee, G.W., Bauder, J.W. 1986. Particle size analysis. In: Klute, A. (Ed.), Methods of Soil Analysis Part 1: Physical and Mineralogical Methods $2^{\text {nd }}$ Edition. Soil Science Society of America, Madison, WI. pp. 383-411.

Getter, K.L., Rowe, D.B., Robertson, G.P., Cregg, B.M., and Andresen, J.A. 2009. Carbon sequestration potential of extensive green roofs. Environmental Science and Technology, 43(19): 7564-7570.

Golubiewski, N.E. 2006. Urbanization increases grassland carbon pools: effects of landscaping in Colorado's front range. Ecological Applications, 16(2): 555-571.

Graney, J.R., Eriksen, T.M. 2004. Metals in pond sediments as archives of anthropogenic activities: a study in response to health concerns. Applied Geochemistry, 19(7): 1177-1188.

Greenway, M. 2010. Wetlands and ponds for stormwater treatment in subtropical Australia: their effectiveness in enhancing biodiversity and improving water quality? Journal of Contemporary Water Research \& Education, 146: 22-38.

Hunt, W.F., Greenway, M., Moore, T.C., Brown, R.A., Kennedy, S.G., Line, D.E., Lord, W.G. 2011. Constructed stormwater wetland installation and maintenance: are we getting it right? Journal of Irrigation and Drainage Engineering, 137(8): 469-474.

Intergovernmental Panel on Climate Change (IPCC). 2013. Climate Change 2013: The Physical Science Basis. Contribution of Working Group I to the Fifth Assessment Report of the Intergovernmental Panel on Climate Change. Cambridge University Press, Cambridge, United Kingdom and New York, NY, USA.

International Stormwater BMP Database. 2010. Pollutant Category Summary: Nutrients. December 2010. URL: http://www.bmpdatabase.org/performance-summaries.html. Assessed: 04 July 2015.

Jobbágy, E.G. and Jackson R.B. 2000. The vertical distribution of soil organic carbon and its relation to climate and vegetation. Ecological Applications, 10: 423-436.

Kandulu, J.M., Connor, J.D., MacDonald, D.H. 2014. Ecosystem services in urban water investment. Journal of Environmental Management, 145: 43-53.

Knowles, R. 1982. Denitrification. Microbiology and Molecular Biology Reviews, 46(1), 43-70.

Lal, R. 2004. Soil carbon sequestration to mitigate climate change. Geoderma, 123(1-2): 1-22. 
Lenhart, H.A. and Hunt, W.F. 2011. Evaluating four stormwater performance metrics with a North Carolina coastal plain stormwater wetland. Journal of Environmental Engineering, 137(2): 155-162.

Lenhart, H.A., Hunt, W.F., Burchell, M.R. 2012. Harvestable nitrogen accumulation for five stormwater wetland plant species: trigger for stormwater control measure maintenance? Journal of Environmental Engineering, 138(9), 972-978.

Lott, R.B. and Hunt, R. 2001. Estimating evapotranspiration in natural and constructed wetlands. Wetlands, 21(4): 614-628.

Lucke, T and Nichols, P.W.B. 2015. The pollution removal and stormwater reduction performance of street-side bioretention basins after ten years in operation. Science of the Total Environment, 536: 784-792.

Lundberg, K., Carling, M., and Lindmark, P. 1999. Treatment of highway runoff: a study of three detention ponds. Science of the Total Environment, 235(1-3): 363-365.

Maryland Department of the Environment (MDE). 2016. Stormwater Design Manual, Volumes I and II. Baltimore, Maryland, USA. Website:

http://mde.maryland.gov/programs/Water/StormwaterManagementProgram/MarylandStormwate rDesignManual/Pages/Programs/WaterPrograms/SedimentandStormwater/stormwater_design/in dex.aspx. Assessed: 03 September 2016.

Merriman, L.S. and Hunt, W.F. 2014. Maintenance versus Maturation: Constructed stormwater wetland's fifth year water quality and hydrologic assessment. Journal of Environmental Engineering, 140(10): 05014003

Millennium Ecosystem Assessment (MEA). 2005. Ecosystem Services and Human Well-Being: Wetlands and Water: Synthesis. Millennium Ecosystem Assessment Report to the Ramsar Convention. World Resources Institute, Washington, D.C. Assessed 15 June 2015. http://www.millenniumassessment.org/en/index.html

Moore, T.L.C. and Hunt, W.F. 2013. Predicting the carbon footprint of urban stormwater infrastructure. Ecological Engineering, 58: 44-51.

Moore, T.L.C., Hunt, W.F. 2012. Ecosystem service provision by stormwater wetlands and ponds - a means for evaluation? Water Research, 46: 6811-6823.

National Climatic Data Center (NCDC). 2014. U.S. Annual Station Normals (1981-2002). Weather Stations USC00314962 (Lewiston, NC), USC00319467 (Wilmington, NC), USC00316422 (Richlands, NC), USW00093807 (Winston-Salem, NC), USC00319097 (Raleigh, NC), USC00311975 (Concord, NC). National Oceanic and Atmospheric Administration. U.S. Department of Commerce. http://www.ncdc.noaa.gov.

National Environmental Agency of Singapore (NEA). 2015. Climatic Information: Weather Statistics. Singapore, Singapore. http://www.nea.gov.sg/weather-climate/climateinformation/weather-statistics. Assessed 11 June 2015. 
Natural Resources Conservation Service (NRCS). 2014. Web Soil Survey. URL: http://websoilsurvey.sc.egov.usda.gov/App/HomePage.htm.

North Carolina Department of Environmental Quality (NCDEQ). 2016. Stormwater BMP Design Guidance. Raleigh, NC, USA. URL: http://deq.nc.gov/sw-bmp-manual. Assessed: 03 September 2016.

Neill, C., Cerri, C., Melillo, J., Feigl, B., Steudler, P., Moraes, J., Piccolo, M. 1998. Stocks and dynamics of soil carbon following deforestation for pasture in Rondonia. Soil Processes and the Carbon Cycle, CRC Press, Boca Raton, 9-28.

Newell, R.G., Pizer, W.A., Raimi, D. 2013. Carbon markets 15 years after Kyoto: Lessons learned, new challenges. Journal of Economic Perspectives, 27(1): 123-146.

Oades, J.M. 1988. The retention of organic matter in soils. Biogeochemistry, 5, 33-70.

Paul, E.A. 1984. Dynamics of soil organic matter. Plant and Soil, 76: 275-285.

Peel, M.C., Finlayson, B.L., McMahon, T.A. 2007. Updated world map of the Köppen-Geiger climate classification. Hydrology and Earth Systems Science, 11: 1633-1644.

Pontier, H., Williams, J.B., May, E. 2004. Progressive changes in water and sediment quality in a wetland system for control of highway runoff. Science of the Total Environment, 1-3(5): 215224.

Post, W.M., and Kwon, K.C. 2000. Soil carbon sequestration and land-use change: processes and potential. Global Change Biology, 6: 317-327.

Pouyat, R. Yesilonis, I., Golubiewski, N. 2009. A comparison of soil organic carbon stocks between residential turf grass and native soil. Urban Ecosystems, 12(1): 45-62.

Qian, Y., and Follett, R.F. 2002. Assessing soil carbon sequestration in turfgrass systems suing long-term soil testing data. Agronomy Journal, 94: 930-935.

Riedell, W.E., Osborne, S.L., Schumacher, T.E., Pikul, J.L. 2011. Grassland canopy management and native tallgrass species composition effects on $\mathrm{C}$ and $\mathrm{N}$ in grass canopies and soil. Plant and Soil, 338 (1-2): 51-61

Sala, O.E., Parton, W.J., Joyce, L.A., Lauenroth, W.K. 1988. Primary production of the central grassland region of the United States. Ecology, 69: 40-45.

Schlesinger, W.H. 1977. Carbon balance in terrestrial detritus. Annual Review of Ecology and Systematics, 8: 51-81.

Swedish Forest Soil Inventory (SFSI). Swedish National Survey of Forest Soils and Vegetation. Department of Forest Soils. Swedish University of Agricultural Sciences. http://wwwmarkinfo.slu.se/eng/index.html. Assessed 15 June 2015. 
Torn, M.S., Trumbore, S.E., Chadwick, O.A., Vitousek, P.M., Hendricks, D.M. 1997. Moneral control of soil organic carbon storage and turnover. Nature, 389: 170-173.

United Nations (UN). 2010. World Urbanization Prospects, the 2009 Revision: Highlights. Department of Economic and Social Affairs, Population Division

Vezzaro, L, Eriksson, E., Ledin, A., Mikkelsen, P.S. 2011. Modelling the fate of organic micropollutants in stormwater ponds. Science of the Total Environment, 409(13): 2597-2606.

Walker, D.J. 2001. Modeling sedimentation processes in a constructed stormwater wetland. Science of the Total Environment, 266: 61-68.

Wadzuk, B.M., Rea, M., Woodruff, G., Flynn, K., and Traver, R.G. 2010. Water quality performance of a constructed stormwater wetland for all flow conditions. Journal of American Water Resources Association, 46(2): 385-394.

Webb, W.L., Szarek, S., Lauenroth, W.K., Kinerson, R., Smith, M. 1978. Primary production and water use on native forest, grassland, and desert ecosystems. Ecology, 59: 1239-1247.

West, T.O., Marland, G., King, A.W., Post, W.M., Jain, A.K. Andrasko, K. 2004. Carbon management response curves: estimates of temporary soil carbon dynamics. Environmental Management, 33(4): 507-518.

Wolf. D.C. and Wagner, G.H. 2005. In: (Eds.) Sylvia, D.M., Fuhrmann, J.J., Hartel, P.G., Zuberer, D.A. Carbon transformations and soil organic matter formation. ${ }^{\text {nd }}$ Edition. Pearson Prentice Hall, Upper Saddle Rive, New Jersey. pp. 285-332.

World Weather Information Service (WWIS). World Meteorological Organization. 30-year Normals: 1961-1990. www.worldweather.org. Assessed: 08 March 2014.

Zhou, P., Luukkanen, O., Tokola, T., Nieminen, J. 2008. Effect of vegetation cover on soil erosion in a mountainous watershed. Catena, 75(3), 319-325. 
